\title{
Biodegradation and Sugar Release from Canola Plant Biomass by Selected White Rot Fungi
}

\author{
Omoanghe S. Isikhuemhen ${ }^{1 *}$, Nona A. Mikiashvili1, Zachary N. Senwo ${ }^{2 *}$, \\ Elijah I. Ohimain ${ }^{3}$ \\ ${ }^{1}$ Department of Natural Resources \& Environmental Design, North Carolina A\&T State University, \\ Greensboro, USA \\ ${ }^{2}$ Department of Biological \& Environmental Sciences, Alabama Agricultural \& Mechanical University, \\ Normal, USA \\ ${ }^{3}$ Niger Delta University, Wilberforce Island, Nigeria \\ Email: *omon@ncat.edu, ${ }^{*}$ zachary.senwo@aamu.edu
}

Received 20 August 2014; revised 5 October 2014; accepted 20 October 2014

Copyright (C) 2014 by authors and Scientific Research Publishing Inc.

This work is licensed under the Creative Commons Attribution International License (CC BY). http://creativecommons.org/licenses/by/4.0/

(c) (7) Open Access

\begin{abstract}
Canola crop is rich in plant biomass. It is considered a major cash crop in North America and a potential source for biofuel. We evaluated six strains of white rot basidiomycetes under solid state fermentation (SSF) for their potentials to secrete oxidative and hydrolytic enzymes to biodegrade canola plant biomass (CPB), and release sugars. Fuscoporia gilva and Pleurotus tuberregium produced high amount of laccase (440.86 $\mathrm{U} / \mathrm{L}$ and $480.63 \mathrm{U} / \mathrm{L}$ at day 7$)$, as well as carboxylmethylcellulase (CMCase) $(4.78 \mathrm{U} / \mathrm{mL}$ at day 21 and $3.13 \mathrm{U} / \mathrm{mL}$ at day 14$)$ and xylanase $(4.48 \mathrm{U} / \mathrm{mL}$ and 7.8 $\mathrm{U} / \mathrm{mL}$ at day 21), respectively. Bjerkandera adusta showed high amount of MnP (50.4 U/L) and peroxidase (64.5 $\mathrm{U} / \mathrm{L})$, relative to the other strains. Loss of organic matter peaked after 21 days of incubation in all the tested strains; however, the best result (34.0\%) was shown in P. tuberregium. The highest lignin loss was observed in Coriolopsis caperata strains. Among the sugar polymers, hemicellulose was highly degraded by $P$. tuberregium and $P$. pulmonarius $(4.1 \%-4.6 \%)$, while cellulose $(3.3 \%-4.3 \%)$ was mainly degraded by $F$. gilva and $B$. adusta. Glucose was the dominant sugar released by all the fungi tested, with the highest concentration of $1.25 \mathrm{mg} / \mathrm{mL}$ produced by $B$. adusta at day 14 of incubation. Results indicate that selected white rot fungi can achieve significant delignification of CPB within 14 days of solid state fermentation. Their importance in low cost pretreatment of lignocellulosic biomass prior to conversion into biofuels and bio-products of economic importance is discussed.
\end{abstract}

\footnotetext{
${ }^{*}$ Corresponding authors.
}

How to cite this paper: Isikhuemhen, O.S., Mikiashvili, N.A., Senwo, Z.N. and Ohimain, E.I. (2014) Biodegradation and Sugar Release from Canola Plant Biomass by Selected White Rot Fungi. Advances in Biological Chemistry, 4, 395-406. 


\section{Keywords}

\section{Canola Plant Biomass, Bio-Delignification, White Rot Fungi, Lignocellulose}

\section{Introduction}

Canola is a lignocellulosic rich plant biomass and bioenergy crop in North America [1]. The plant biomass is usually left as trash in fields or ploughed back into the soil after harvest. Its basal stems and roots are woody, and slower to decompose relative to the stem portions [2]. Lignin (14.2\%), cellulose (42.4\%), and hemicellulose (16.4\%) are major components of the canola plant material [3]. Among these fractions, lignin consists of a heterogeneous and highly cross-linked polymer [4], while cellulose is organized as glucose polymeric long linear chains and is arranged in various levels of fibrils [5] [6]. Hemicelluloses, in contrast, are ramified polymers composed of various types of carbohydrates and phenolic compounds, among which there are xylan, glucan and arabinoglucan that form the sugar backbone in its structure [7].

White rot fungi (WRF) have been studied extensively due to their potential value in biopulping, bleaching, and other lignin removal schemes [8]. They can be cultivated on different lignocellulosic materials: agricultural wastes, sawdust, paper products, etc. [9] [10]. Some WRF have selective delignification properties, by which they preferentially degrade lignin over cellulose [11]. There are several reports on the application of WRF in the delignification of plant residues to improve digestibility [12]-[15]. The pretreatment of biomass for sugar release and delignification to enhance their use in bio-energy applications are also reported [16] [17]. Ohgren et al. [18] reported that sugar yields from both hemicellulose and cellulose are critical parameters for an economically-feasible ethanol production process; and that partial delignification of pretreated biomass increases the overall yield of sugar.

Oxidative and hydrolytic extracellular enzymes (manganese peroxidase, laccase, cellulasses and xylanases) from these white rot fungi are able to depolymerize lignocellulosics [19] [20]. There is evidence that the extracellular polysaccharides (EPS) produced by lignocellulolytic fungi play an important role in the degradation process [21]. These EPS can immobilize the exocellular enzymes. According to Catley [22], the gel formed by these biopolymers prevents the hyphal dehydration, permits cell adherence to other cells or surfaces and could possibly select molecules that have positive influence on environmental degradation.

The conversion of lignocellulosics into fermentable sugars is a key limiting step in industrial processes of cellulosic ethanol production from biomass. Industrially-produced biomass sugars require harsh physicalchemical pretreatments (such as steam explosion, with or without diluted sulfuric acid) to loosen lignin and release fibrils of cellulose and monomers from lignocellulosic components [5].

The increasing demand for canola oil and press cake for food, feed and bioenergy applications has led to increased acreage used for canola cultivation, and the production of enormous amounts of biomass as waste. There is the lack of information or studies regarding the biodegradation or bioconversion of canola biomass using white rot fungi. Our objective was to determine the enzymatic potentials of selected WRF on the biodegradation and release of sugar from canola plant biomass under solid state fermentation (SSF) conditions.

\section{Materials and Methods}

\subsection{Organisms and Cultivation}

The white rot fungi used in this study included two strains of Coriolopsis caperata (Berk.) Murrill, and one each of Bjerkandera adusta (Willd.) P. Karst, Fuscoporia gilva (Schwein.) T. Wagner and M. Fisch., Pleurotus tuberregium (Fr.) Sing., and Pleurotus pulmonarius (Fr.) Quél. They were obtained from culture collections at the Mushroom Biology and Fungal Biotechnology Laboratory (MBFBL), North Carolina Agricultural \& Technical State University, Greensboro, NC, USA.

The fungal inoculula were prepared by cultivating each fungus in basal medium of glucose $\left(10 \mathrm{~g} \cdot \mathrm{L}^{-1}\right)$; $\mathrm{KH}_{2} \mathrm{PO}_{4}\left(0.8 \mathrm{~g} \cdot \mathrm{L}^{-1}\right) ; \mathrm{NH}_{4} \mathrm{NO}_{3}\left(2 \mathrm{~g} \cdot \mathrm{L}^{-1}\right) ; \mathrm{Na}_{2} \mathrm{HPO}_{4}\left(0.4 \mathrm{~g} \cdot \mathrm{L}^{-1}\right) ; \mathrm{MgSO}_{4} \cdot 7 \mathrm{H}_{2} \mathrm{O}\left(0.5 \mathrm{~g} \cdot \mathrm{L}^{-1}\right)$; and yeast extract (2 $\left.\mathrm{g} \cdot \mathrm{L}^{-1}\right)$. The following microelements were added to the basal medium: $\mathrm{ZnSO}_{4} \cdot 7 \mathrm{H}_{2} \mathrm{O}\left(0.001 \mathrm{~g} \cdot \mathrm{L}^{-1}\right) ; \mathrm{FeSO}_{4} \cdot 7 \mathrm{H}_{2} \mathrm{O}$ $\left(0.005 \mathrm{~g} \cdot \mathrm{L}^{-1}\right) ; \mathrm{CaCl}_{2} \cdot 2 \mathrm{H}_{2} \mathrm{O}\left(0.06 \mathrm{~g} \cdot \mathrm{L}^{-1}\right) ; \mathrm{CuSO}_{4} \cdot 7 \mathrm{H}_{2} \mathrm{O}\left(0.005 \mathrm{~g} \cdot \mathrm{L}^{-1}\right) ; \mathrm{MnSO}_{4} \cdot \mathrm{H}_{2} \mathrm{O}\left(0.005 \mathrm{~g} \cdot \mathrm{L}^{-1}\right)$. The medium 
was adjusted to $\mathrm{pH}$ 6.0. The fungal mycelia cultivation was performed in $100 \mathrm{~mL}$ of the above medium in 500 $\mathrm{mL}$ flasks sterilized at $121^{\circ} \mathrm{C}$ for 15 minutes, then inoculated with 5 agar blocks ( $4 \mathrm{~mm}$ diameter) containing actively growing mycelia (7-day-old) of test fungi. The flasks inoculated with C. caperata, B. adusta, or F. gilva were incubated at $25^{\circ} \mathrm{C}$, while those inoculated with $P$. tuberregium and $P$. pulmonarius were incubated at $30^{\circ} \mathrm{C}$.

\subsection{Solid State Fermentation}

The solid state fermentation was conducted in $250 \mathrm{~mL}$ Erlenmeyer flasks, containing $5 \mathrm{~g}$ (dry weight) of milled canola plant materials (substrate) mixed with water (ratio 1:4) and sterilized at $121^{\circ} \mathrm{C}$ for $15 \mathrm{~min}$. Flasks containing the sterilized substrates were each inoculated with $2 \mathrm{~mL}$ homogenate of inoculum (43 - $52 \mathrm{mg}$ of mycelia dry weight) prepared as described above, and incubated at temperatures designated for the various strains. Three replicate sample flasks per strain were withdrawn at 7, 14 and 21 days of incubation. Each sample was extracted with $40 \mathrm{~mL}$ sodium acetate buffer $(100 \mathrm{mM}, \mathrm{pH} 5.0)$, for $2 \mathrm{~h}$ at $4^{\circ} \mathrm{C}$ and filtered through Whatman 1 paper. The filtrate was centrifuged at $6000 \mathrm{rpm}$ for $15 \mathrm{~min}$ to obtain the crude extract, polysaccharide and water soluble sugar content. The leftover solid materials from each flask were dried at $60^{\circ} \mathrm{C}$ to reach a constant weight and values obtained was used to calculate lost organic matter (LOM), i.e., the percent difference in dry weight between the test substrate and the control (uninoculated substrate) [16] [23]. The leftover solid materials were also analyzed for lignin, cellulose, and hemicellulose components using the method for dietary fiber [24].

\subsection{Enzyme Activity Assays}

Laccase activity was determined using 2,2'-azino-bis (3-ethylbenzthiazoline-6-sulphonic acid (ABTS) as substrate and absorbance measured at $420 \mathrm{~nm}$ [25]. The reaction mixture contained $50 \mathrm{mM}$ acetate buffer (pH 3.8), $1 \mathrm{mM}$ ABTS, and $100 \mu \mathrm{L}$ diluted culture filtrate. Manganese depended peroxidase (MnP) activity was assayed by the oxidation of phenol red. The reaction buffer $(1 \mathrm{~mL})$ contained sodium lactate-succinate buffer $(25 \mathrm{mM}$, $\mathrm{pH}$ 4.5), $2 \mathrm{mM} \mathrm{H}_{2} \mathrm{O}_{2}, 3 \mathrm{mM}$ Phenol Red, and culture filtrate. The reaction was terminated by the addition of $2 \mathrm{M}$ $\mathrm{NaOH}$ and absorbance recorded at $610 \mathrm{~nm}$. All enzyme assays were carried out at room temperature $\left(25^{\circ} \mathrm{C}\right)$. One unit of enzyme activity was defined as an amount of enzyme that transformed $1 \mu \mathrm{mol}$ substrate per minute [26].

Carboxylmethylcellulase (CMCase) activity was assayed with 1\% solution of carboxymethyl cellulose as enzyme substrate in $0.05 \mathrm{M}$ citrate buffer ( $\mathrm{pH}$ 5.0) according to IUPAC recommendations [27]. The reaction mixture was incubated for 10 minutes in a buffer at a temperature of $50^{\circ} \mathrm{C}$. Xylanase activity was assayed using a $1 \%$ solution of xylan from birch wood (Roth 7500) as substrate in $0.05 \mathrm{M}$ citrate buffer (pH 5.0). The release of glucose and xylose, respectively, in 10 minutes at $50^{\circ} \mathrm{C}$ was measured using the dinitrosalicylic acid method [28]. One unit of enzyme activity is defined as $1 \mu \mathrm{mol}$ of glucose or xylose equivalents released per minute under the given conditions.

The 1,4- $\beta$-glucosidase (EC 3.2.1.2) and 1,4- $\beta$-xylosidase (EC 3.2.1.37) activities were determined by measuring the rate of hydrolysis of, $p$-nitrophenyl- $\beta$-D-glucopyranoside and $p$-nitrophenyl- $\beta$-D-xylopyranoside respectively, as described by Poutanen and Puls [29]. The reaction mixture containing $1.8 \mathrm{~mL}$ of $2.5 \mathrm{mM}$ substrate and $0.2 \mathrm{~mL}$ of the culture extract filtrate were incubated at $50^{\circ} \mathrm{C}$ for 10 minutes. The reaction was stopped by adding $1 \mathrm{~mL}$ of $1 \mathrm{M} \mathrm{Na}_{2} \mathrm{CO}_{3}$ into the reaction mixture. The enzyme quantity catalyzing the release of $1 \mu \mathrm{mol}$ of $p$-nitrophenol per min under these conditions was considered to be a unit of enzyme activity.

\subsection{Exopolysaccharides Assay}

Crude exopolysaccharides (EPS) was determined as previously reported, briefly, 1 volume of crude extract from the biomass was mixed with 4 volumes of absolute ethanol, stirred and left for 24 hours at $4^{\circ} \mathrm{C}$. Precipitated EPS were collected by centrifugation at $6000 \mathrm{~g}$ for $20 \mathrm{~min}$, dried and weighed [30].

\subsection{Sugar Assay}

The sugar content of the crude extract filtrate (pH 5.5) was quantitatively determined as reported previously, on a HPLC system utilizing Shodex KC-811 column [16].

\subsection{Statistical Analysis}

SPSS software version 17 (SPSS Inc., Chicago) was used for statistical analysis. A one-way analysis of variance 
was carried out at $\alpha=0.05$, and Duncan's multiple range test was used to compare the enzyme activities, polysaccharide production and biomass utilization, while Dunnett's statistics was used to compare the mean concentrations at the various sampling days with the un-inoculated as control.

\section{Results and Discussions}

\subsection{Macromolecules Degradation and Polysaccharide Production}

The results indicate that among the three macromolecules, only lignin was significantly degraded (Table 1 ). After seven days only B. adusta showed significant degradation in lignin content. However, after 14 days, the extent of degradation by all the organisms was significantly different $(P<0.05)$ from the control. Although the extent of the degradation differed among the tested organisms, $P$. pulmonarius had the highest degradation rates (residual lignin content had decreased from $15.24 \%$ to $10.9 \%$ ), which was significantly different $(P<0.05)$ from the other organisms (Table 1). However, after 21 days of incubation, all the organisms degraded lignin significantly $(P<0.05)$, with the least residual lignin at $8.6 \%$ and $9.2 \%$ on substrate incubated with $C$. caperata 1 and 2, respectively, and followed by P. pulmonarius (10\%). Significant degradation of hemicellulose was observed in B. adusta and P. pulmonarius and C. caperata 2 after seven days and $P$. tuberregium after 14 days. Cellulose degradation was negligible in all strains tested except in $B$. adusta, where significant degradation was observed after 14 days. All macromolecule degradation data are shown in Table 1.

Analysis of canola plant materials by the selected white rot fungi strains indicate selective delignification, since only the lignin component was significantly degraded, while the hemicelluloses and cellulose remained relatively intact. The selective biodelignification of lingocellulosic materials has high biotechnological importance in biofuels production, bioenergy applications [17] [18], feed and forage digestibility [6], as well as other environmental applications especially in the areas of waste conversion and recycling [31] [32].

In the early stages of fermentation, WRF have the added advantage of selective lignin biodegradation while conserving the cellulose in various plant biomass. In this study, the highest lignin loss was recorded in the two $C$. caperata isolates (38.7\% and $42.9 \%)$, followed by P. pulmonarius $(33.3 \%)$ and the rest of the fungi $(14.7 \%$ 24.0\%) after 21 days of incubation. Akin et al. [12] showed lignin degradation of Ceriporiopsis subvermispora (29\% - 33\%), and Cyathus stercoreus (63\% - 77\%) after 6 weeks of incubation with Bermuda grass. Rois and Eyzaguirre [32] reported the selective degradation of lignin by the fungus Ganoderma australe and similar reports exist for various WRF tested for selective biomass delignification with Pleurotus, Pycnoporus, Ischnoderma, Phlebia spp [4] [33] [34]. Hatakka [35] studied the pretreatment of wheat straw by 19 WRF and found that $35 \%$ of the straw was converted to sugar by Pleurotus ostreatus in 5 weeks.

In all the WRF tested, the loss of organic matter (LOM) was highest after 21 days in all strains tested (Table 2). It is also visible that the organisms that showed highest degradation at the beginning did not turn out to be those with the highest degradation after three weeks, indicating the variability in degradation capacity versus fermentation time. In $P$. tuberregium, lignin correlated inversely with LOM $(\mathrm{r}=0.999 ; P<0.05)$, which clearly indicated that lignin biodegradation is associated with LOM. A loss in organic matter of $34 \%$ was recorded for $P$. tuberregium, which was significantly different from the other tested WRF (23.6\% - 25.8\%). This result recorded during this study is within the range (12.8\% - 34.1\%) recorded for Grifola frondosa during the biodegradation of oak sawdust in a 55-day fermentation experiment [36] and was lower than 55.8\% recorded for Lentinus squarrosulus with cornstalk after 30 days of incubation [16]. However, the fact that this level of degradation happened in P. tuberregium and other tested strains within three weeks indicates their rapid degradation capacity, which may be useful in the pretreatment/delignification of biomass prior to use in producing cellulosic ethanol and other biomass to bio-products applications.

Exopolysaccharides (EPS) produced by all the test organisms at the various incubation periods, were all significantly higher $(P<0.01)$ than the control $(1.4 \mathrm{mg} / \mathrm{mL})$ (Table 2). Among the different incubation times, polysaccharide production was highest after 14 days, followed by after 21 days and least after 7 days. The highest polysaccharide $(5.3 \mathrm{mg} / \mathrm{mL})$ was produced by F. gilva and C. caperata 2 after 14 days of incubation. Other investigators have similarly reported the production of polysaccharide during the fungal degradation of wood biomass. L. squarrosulus produced polysaccharides attaining peak concentration of 4.0 and $5.13 \mathrm{mg} / \mathrm{mL}$ after 18 and 24 days of incubation [16]. Mikiashvilli et al. [36] found that $G$. frondosa produced polysaccharide ranging 3.2 - $3.5 \mathrm{mg} / \mathrm{mL}$ under SSF after 55 days of incubation. The roles of EPS secreted by fungi include mycelia adhesion to the substrate, protection against dehydration; and storage as a carbon source [21]. Protection against 
Table 1. Lignin, cellulose and hemicellulose content in canola plant biomass incubated with different species of Basidiomycetes.

\begin{tabular}{|c|c|c|c|c|}
\hline Species & Days & Hemicellulose (\%) & Cellulose (\%) & Lignin (\%) \\
\hline \multirow[t]{3}{*}{ C. caperata 1} & 7 & $16.98 \pm 0.60 \mathrm{def}$ & $45.95 \pm 0.90 \mathrm{~cd}$ & $14.92 \pm 0.33 \mathrm{ijk}$ \\
\hline & 14 & $16.81 \pm 0.45$ def & $45.55 \pm 0.42 \mathrm{bcd}$ & $11.87 \pm 0.40 \mathrm{def}^{*}$ \\
\hline & 21 & $16.41 \pm 0.40$ cde & $46.51 \pm 0.38 \mathrm{~cd}$ & $8.68 \pm 0.83 a^{*}$ \\
\hline \multirow[t]{3}{*}{ C. caperata 2} & 7 & $15.88 \pm 0.57 \mathrm{abcd}$ & $44.20 \pm 0.46 \mathrm{abc}$ & $15.18 \pm 0.64 \mathrm{ijk}$ \\
\hline & 14 & $17.09 \pm 0.34 \mathrm{def}$ & $45.32 \pm 1.54 \mathrm{bcd}$ & $12.96 \pm 1.42 \mathrm{fgh}^{*}$ \\
\hline & 21 & $17.08 \pm 0.55$ def & $45.96 \pm 0.67 \mathrm{~cd}$ & $9.24 \pm 1.25 \mathrm{ab}^{*}$ \\
\hline \multirow[t]{3}{*}{ B. adusta } & 7 & $15.61 \pm 0.44 \mathrm{abc}^{*}$ & $44.28 \pm 0.63 \mathrm{abc}$ & $13.83 \pm 0.37$ ghi* $^{*}$ \\
\hline & 14 & $16.18 \pm 0.47$ bcde & $43.34 \pm 1.52 \mathrm{a}^{*}$ & $11.88 \pm 0.54 \mathrm{def}^{*}$ \\
\hline & 21 & $16.93 \pm 0.45 \mathrm{def}$ & $44.51 \pm 1.92 \mathrm{abc}$ & $11.66 \pm 1.19 \mathrm{def}^{*}$ \\
\hline \multirow[t]{3}{*}{ F. gilva } & 7 & $16.99 \pm 0.84$ def & $46.04 \pm 1.39 \mathrm{~cd}$ & $15.75 \pm 0.58 \mathrm{ijk}$ \\
\hline & 14 & $16.84 \pm 0.31 \mathrm{def}$ & $44.74 \pm 0.39$ abcd & $12.52 \pm 0.68 \mathrm{ef}^{*}$ \\
\hline & 21 & $17.51 \pm 0.32$ def & $43.83 \pm 0.39 a b$ & $12.76 \pm 0.60 \mathrm{~g}^{*}$ \\
\hline \multirow[t]{3}{*}{ P. tuberregium } & 7 & $16.59 \pm 1.20 \mathrm{cdef}$ & $44.99 \pm 0.45 \mathrm{abcd}$ & $15.03 \pm 0.29 \mathrm{ijk}$ \\
\hline & 14 & $14.95 \pm 0.17 \mathrm{a}^{*}$ & $45.32 \pm 2.08 \mathrm{bcd}$ & $14.26 \pm 1.63 \mathrm{ij}^{*}$ \\
\hline & 21 & $16.06 \pm 0.49$ bcde & $45.88 \pm 0.87 \mathrm{~cd}$ & $11.39 \pm 0.36 \mathrm{de}^{*}$ \\
\hline \multirow[t]{3}{*}{ P. pulmonarius } & 7 & $15.38 \pm 0.04 \mathrm{ab}^{*}$ & $44.87 \pm 1.39 \mathrm{abcd}$ & $14.06 \pm 0.49$ hij $^{*}$ \\
\hline & 14 & $15.36 \pm 0.22 \mathrm{ab}^{*}$ & $44.54 \pm 0.37 \mathrm{abc}$ & $10.92 \pm 0.62 \mathrm{~cd}^{*}$ \\
\hline & 21 & $16.14 \pm 0.16$ def & $44.77 \pm 0.07 \mathrm{abcd}$ & $10.05 \pm 0.20 \mathrm{bc}$ \\
\hline Uninoculate substrate & & $16.84 \pm 0.82 \mathrm{def}$ & $45.33 \pm 0.46 \mathrm{bcd}$ & $15.24 \pm 0.28 \mathrm{ijk}$ \\
\hline
\end{tabular}

Each value is expressed as mean \pm SE $(n=3)$. ${ }^{*}$ Measurements that is significantly different from the control at $\alpha<0.05$. Means along the column with the same alphabetic numbers are not significantly different at $\alpha>0.05$.

Table 2. Loss of organic matter and exopolysaccharides content in canola plant biomass during solid state fermentation with selected white rot fungi.

\begin{tabular}{cccc}
\hline Species & Days & LOM (\%) & Exopolysaccharides (mg/ml) \\
\hline C. caperata 1 & 7 & $17.47 \pm 1.81 \mathrm{e}$ & $2.20 \pm 0.17 \mathrm{a}$ \\
& 14 & $20.0 \pm 0.87 \mathrm{~cd}$ & $4.10 \pm 0.12 \mathrm{bc}$ \\
& 21 & $23.93 \pm 1.40 \mathrm{~b}$ & $2.37 \pm 0.32 \mathrm{a}$ \\
C. caperata 2 & 7 & $18.20 \pm 1.83 \mathrm{de}$ & $5.33 \pm 0.12 \mathrm{f}$ \\
& 14 & $18.93 \pm 2.04 \mathrm{de}$ & $3.97 \pm 0.09 \mathrm{~b}$ \\
& 21 & $24.93 \pm 2.21 \mathrm{~b}$ & $2.33 \pm 0.24 \mathrm{a}$ \\
B. adusta & 7 & $17.20 \pm 1.40 \mathrm{e}$ & $4.83 \pm 0.09 \mathrm{de}$ \\
& 14 & $17.20 \pm 0.72 \mathrm{e}$ & $4.70 \pm 0.31 \mathrm{cde}$ \\
F. gilva & 21 & $25.47 \pm 0.31 \mathrm{~b}$ & $4.83 \pm 0.15 \mathrm{de}$ \\
& 7 & $17.20 \pm 1.40 \mathrm{e}$ & $5.37 \pm 0.29 \mathrm{f}$ \\
& 14 & $17.20 \pm 0.72 \mathrm{e}$ & $4.53 \pm 0.35 \mathrm{bcd}$ \\
& 21 & $23.60 \pm 1.74 \mathrm{~b}$ & $4.20 \pm 0.15 \mathrm{bcd}$ \\
& 7 & $12.87 \pm 0.90 \mathrm{f}$ & $4.30 \pm 0.20 \mathrm{bcd}$ \\
& 14 & $16.53 \pm 1.30 \mathrm{e}$ & $4.33 \pm 0.18 \mathrm{bcd}$
\end{tabular}

Each value is expressed as mean $\pm \mathrm{SE}(\mathrm{n}=3)$. Means along the column with the same alphabetic numbers are not significantly different at $\alpha>0.05$. 
dehydration and environmental injuries can be considered a general function of extracellular polysaccharides. The EPS by nature of their glucan content that is composed mainly of glucose, mannose, galactose, xylose and fucose [37] [38], could also be considered as storage compounds, which are consumed by the fungus when exogenous carbon sources are limited [21]. Therefore, the observed decrease in EPS seen in most tested WRF after two weeks of incubation, is a result of degradation and utilization of the sugar monomers in the EPS. Also, some of the sugars detected could actually be by-products from the degradation of the EPS formed in the earlier stages of growth of the fungus on the substrate. Other roles of the extracellular polysaccharides are to facilitate the diffusion and concentration of biodegradation enzymes, and also provide a medium with suitable ionic and $\mathrm{pH}$ conditions for degradation activities [21]. McCue and Shetty [39] investigated the involvement of lignin degradation activities in SSB of soybean by Lentinus edodes and they observed that decreased antioxidant activity was associated with total peroxidase and laccase activity. There are many reports on studies of EPS production by white rot fungi in submerged fermentation [40]-[42]. Their application is in nutraceuticals, especially $\beta$-glucans [43] and environmental remediation [44]. However, studies on exopolysaccharide production in lignocellulosic substrates under SSF have been few [16] [36].

\subsection{Soluble Sugar Content}

Sugars were released to varying extents by the different test organisms during the biodegradation of plant materials (Figure 1). All the organisms released sugars throughout the three weeks incubation period. The highest glucose concentration $(1.25 \mathrm{mg} / \mathrm{mL})$ was determined for $B$. adusta after 14 days of incubation. The highest glucose concentration after 14 days of incubation was consistent among test strains. The trend was that glucose increased after one week, attained peak concentration after two weeks and declined after three weeks except for $C$. caperata 2 and $P$. tuberregium, which had the highest glucose concentration after three weeks. A similar trend was exhibited in trehalose levels except for $C$. caperata 2, which had the highest trehalose released after one week; however, this sugar was not detected with $P$. tuberregium at any time during the fermentation period. It is possible that released trehalose is rapidly metabolized to levels beyond detection limits used in this experiment. Another possibility is that it is never produced in the degradation/metabolic pathways for canola plants by $P$. tuberregium. The highest concentration of xylose, $1.27 \mathrm{mg} / \mathrm{mL}$ and $1.02 \mathrm{mg} / \mathrm{mL}$ was recorded for $F$. gilva after three weeks and $P$. pulmonarius after two weeks respectively. Significant quantities of fructose were only released by C. caperata 1 and B. adusta. It is worthy to mention that $C$. caperata 1 and $C$. caperata 2, though same species, exhibited different behavior on sugar release from the plant materials used in our study (Figure 1).

The conversion of woody biomass to fermentable sugars is challenging and needs to be overcome in cellulosic ethanol production as well as delignification to improve its digestibility when used as feed. Isikhuemhen et al. [16] reported the release of glucose $(0.64-2.96 \mathrm{mg} / \mathrm{mL})$, galactose $(0.62-2.02 \mathrm{mg} / \mathrm{mL})$ and fructose $(0.18$ $0.38 \mathrm{mg} / \mathrm{mL}$ ) during SSF of cornstalk using Lentinus squarrosulus. Ohgren et al. [18] reported 96\% - 104\% glucose yield and $70 \%-74 \%$ xylose yield during the delignification of corn stover using enzymes. In our study, sugar appeared to be partially released, since the hemicelluloses and cellulose were barely degraded by the tested fungi. However, it appears that the period of sugar release peaked after two weeks, after which, there is increased utilization/assimilation of the sugars for fungi growth and metabolism. Our results suggest that to conserve sugars, and enhance pretreatment that achieves biodelignification using WRF should terminate after two weeks in most of the tested fungi. The pretreated material can then be subjected to cellulolytic enzyme activities or other forms of hydrolysis to release sugars, which can be used as feedstock for cellulosic ethanol production. Szczodrak and Fiedurek [14] reported that the production of lignocellulolytic enzymes appears to be the most expensive process, accounting to $43.7 \%$ of the total cost of cellulosic ethanol production. This cost consideration underscores the importance of this study, which used low cost SSF for the selective biodelignification of the plant materials. According to Sun and Cheng [17], the advantages of biological treatment of biomass over conventional chemicals include low energy requirements and mild environmental conditions though the rate of biological pretreatment process is slow.

\subsection{Oxidative Enzyme Activities}

Laccase activities were detected in all species tested (Table 3). In B. adusta, polysaccharide directly correlated with laccase ( $r=0.998 ; P<0.05)$, which suggests that lignin degradation by this fungus could contribute to the synthesis of polysaccharide. Generally, laccase increased after day 7 and attained a peak concentration on day 
- Uninoculate substrate $\mathrm{g}$ days

$\square 14$ days $\square 21$ days
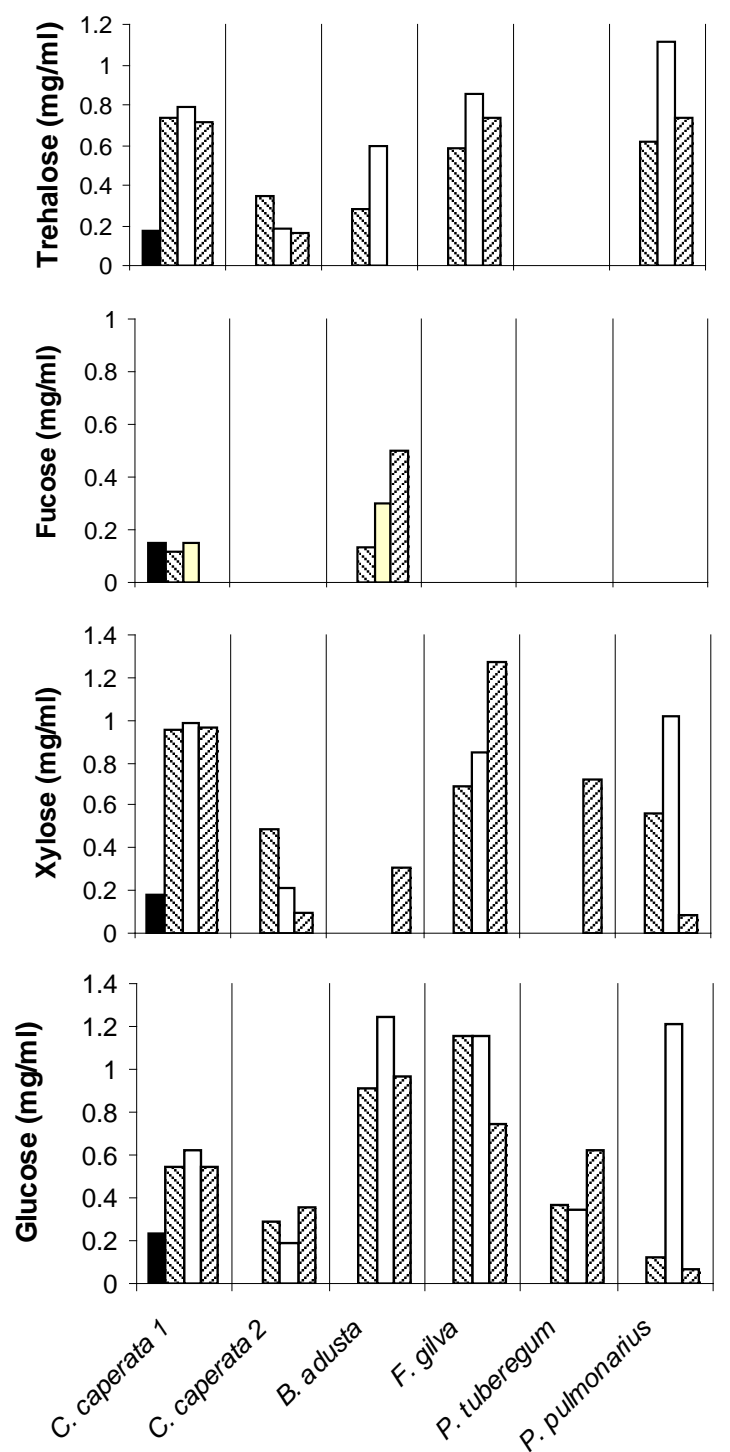

Figure 1. Sugar released during the biodegradation of CPB by white rot fungi. Uninoculated substrate contains: $0.23 \mathrm{mg} / \mathrm{ml}$ glucose, $0.17 \mathrm{mg} / \mathrm{ml}$ trehalose, $0.18 \mathrm{mg} / \mathrm{ml}$ xylose and $0.15 \mathrm{mg} / \mathrm{ml}$ fucose.

14 but declined to lower level on day $21(P<0.05)$ except for $F$. gilva and $P$. tuberregium, which expressed peak enzyme concentration of $440.86 \mathrm{U} / \mathrm{L}$ and $480.63 \mathrm{U} / \mathrm{L}$ respectively after seven days. There was no correlation between laccase and lignin degradation among the fungi tested in this study. Hammel [31] reported that most ligninolytic fungi produce laccase. L. squarrosulus had a peak laccase activity of $154.5 \mathrm{U} / \mathrm{L}$ at day 6 of SSF with cornstalk [16]. Mikiashvilli et al. [36] reported peak laccase activity of 703.3 U/L by G. frondosa under SSF after 55 days of incubation. Laccase has been described as blue copper oxidases that catalyze the oneelectron oxidation of lignin, phenolics and other electron rich compounds [31].

$\mathrm{MnP}$ also exhibited a pattern similar to laccase, increasing after seven days and attaining a peak activity after 14 days (Table 3). B. adusta and $P$. pulmonarius had the highest MnP concentration of $50 \mathrm{U} / \mathrm{L}$ after two weeks, while the least $(0.23 \mathrm{U} / \mathrm{L})$ was recorded for $C$. caperata 1 after 21 days. Unlike laccase and MnP, peroxidase exhibited different pattern among the different organisms tested. For C. caperata 1 and C. caperata 2, peroxidase had 


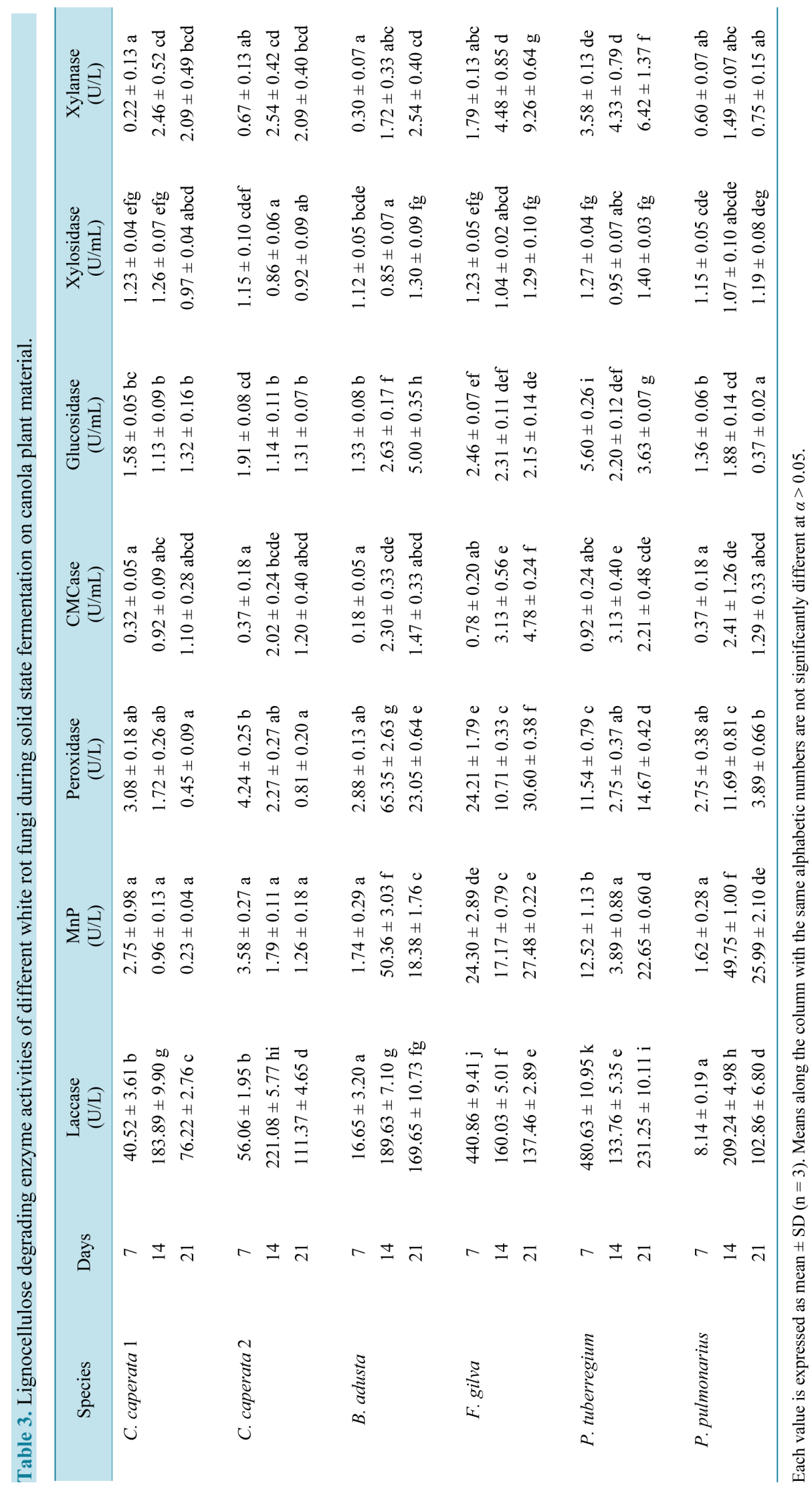


peak concentration after seven days and decreased thereafter. For B. adusta, peroxidase activity of $2.88 \mathrm{U} / \mathrm{L}$ was detected after one week but attained peak activity of $63.3 \mathrm{U} / \mathrm{L}$ after 14 days and declined to $23 \mathrm{U} / \mathrm{L}$ after 21 days $(P<0.05)$. For $F$. gilva, peroxidase had a peak concentration after one week, which decreased after two weeks, but increased again to reach high levels on day 21. For $P$. tuberregium, peroxidase had peak concentration after 21 days, although the concentration on day seven was significantly higher than after day $14(P<0.05)$. $P$. pulmonarius had peak peroxidase concentration after 14 days. In $F$. gilva, polysaccharide was inversely correlated with $\mathrm{MnP}(\mathrm{r}=0.998 ; P<0.05)$ and peroxidase $(\mathrm{r}=0.999 ; P<0.01)$ indicating that both enzymes, could enhance the biosynthesis of polysaccharide. In C. caperata 1 , peroxidase directly correlated with residual lignin ( $\mathrm{r}$ $=0.999 ; P<0.01)$ and therefore indirectly with lignin loss, thus indicating that the enzyme is linked to lignin degradation. It is generally believed that WRF possess the ability to degrade lignin due to the secretion of peroxidases [45] [46]. Rios and Eyzaquirre [32] linked the selective degradation of lignin by Ganoderma australis to the production of MnP under low nitrogen content, low oxygen availability and high humidity. Mikiashvilli et al. [36] reported peak peroxidase activity of $22.6 \mathrm{U} / \mathrm{L}$ for $\mathrm{G}$. frondosa grown on oak sawdust. Isikhuemhen et al. [16] reported a peak MnP activity of $13 \mathrm{U} / \mathrm{L}$ and peroxidase activity of $27.4 \mathrm{U} / \mathrm{L}$ for L. squarrosulus grown under SSF during six days of incubation.

\subsection{Hydrolytic Enzymes Activities}

Four hydrolytic enzymes (CMCase, glucosidase, xylosidase, cellobiosidase and xylanase) were assayed during the study. CMCase concentrations were not significantly different $(P<0.05)$ among the 6 tested strains after seven days (Table 3). However, the general trend exhibited by all the organisms is that CMCase concentration was at its least after seven days, increased to peak concentration after 14 days and declined thereafter, except for F. gilva, which produced the highest concentration of CMCase $(4.78 \mathrm{U} / \mathrm{mL})$ on day 21 . Glucosidase exhibited a different pattern compared to the other enzymes previously presented (Table 3). The least glucosidase enzyme activity was recorded after 21 days for $P$. pulmonarius $(0.33 \mathrm{U} / \mathrm{mL})$, while the highest concentration $(5.0 \mathrm{U} / \mathrm{mL})$ was recorded after 21 for $B$. adusta. It has been demonstrated that during lignocellulosic biomass degradation, glucose yield correlated with the $\beta$-glucosidase activity from mutant Trichoderma atroviride TUB [47].

Among all the tested WRF, $C$. caperata 1 , and $P$. tuberregium produced the least cellobiosidase activity $(<1.0$ $\mathrm{U} / \mathrm{mL}$ ) after 14 days, while the highest activity $(2.17 \mathrm{U} / \mathrm{mL})$ was recorded for $P$. tuberregium after 21 days (Table 3). With C. caperata 2, polysaccharide directly correlated with CMCase $(\mathrm{r}=0.999 ; P<0.05)$ while in $P$. tuberregium, CMCase inversely correlated with glucose $(\mathrm{r}=1.000 ; P<0.01)$. In $F$. gilva, cellulose inversely correlated with CMCase $(\mathrm{r}=1.000 ; P<0.01)$ while in $C$. caperata 2 , cellulose inversely correlated with cellobiosidase $(\mathrm{r}=1.000 ; P<0.01)$ and in $F$. gilva, LOM directly correlated with cellobiosidase $(\mathrm{r}=0.997 ; P<0.05)$. These correlations suggest that these enzymes play some roles in the degradation of macromolecules present in canola plant materials and the release of fermentable sugars.

Xylanase activity exhibited different patterns among the different organisms (Table 3). Among all the organisms, xylanase had the least activity after seven days, but after 14 and 21 days, different patterns were observed among the tested organisms. In C. caperata $1, C$. caperata 2 and $P$. pulmonarius, xylanase concentrations decreased after 14 or 21 days, whereas with B. adusta, F. gilva and P. tuberregium, it increased, and P. tuberregium expressing the highest xylanase activity of $9.2 \mathrm{U} / \mathrm{mL}$ on day 21. In C. caperata 1 , xylanase activity inversely correlated with polysaccharide $(\mathrm{r}=1.000 ; P<0.01)$, while in $P$. tuberregium, lignin inversely correlated with xylanase $(\mathrm{r}=0.998 ; P<0.05)$. This may indicate that xylanase does play some significant roles in the degradation of ligninocellulose and the biosynthesis of polysaccharide. Boominathan and Reddy [48] reported that P. chrysosporum produces lignin degrading enzymes including lignin peroxidases and MnP during secondary metabolism in response to carbon or nitrogen limitations. Other investigators have reported similar hydrolytic enzymatic activities among wood degrading fungi. Isikhuemhen [16] reported the hydrolytic enzyme activities to be $6.0 \mathrm{U} / \mathrm{mL}$ CMCase) and $14.5 \mathrm{U} / \mathrm{mL}$ for xylanase during six days fermentation under of cornstalk under SSF conditions. Kovacs et al. [47] demonstrated that xylose yield correlated with the $\beta$-xylosidase, using mutant, Trichoderma atroviride TUB. Other studies have shown the role of xylanase and xylosidase in the hydrolysis of hemicelluloses during enzymatic saccharification of lignocellulosics [18] [49].

\section{Conclusion}

The results presented indicated that the WRF tested have the ability to selectively degrade the lignin fraction of 
canola plant biomass, and will produce both oxidative and hydrolytic signature enzymes; exopolysaccharides and fermentable sugars. The mode of biodegradation is considered selective delignification, because lignin was significantly degraded compared to hemicelluloses and cellulose components. The results indicated the lack of linear relationships between enzyme activities, macromolecules degradation, exopolysaccharide production and sugar release from plant biomass. This could indicate the various regulatory mechanisms that couple degradation/sugar release in such a way that maintains osmotic equilibrium for optimum physiological and metabolic activities within the different strains. However, selective biodelignification of lignocellulosic materials have several important industrial and biotechnological applications. It could become useful in the pretreatment of plant biomass to enhance feed and forage digestibility and plant biomass biodelignification prior to their use in cellulosic ethanol production, as well as waste conversion to other bioproducts of economic importance. An efficient bioconversion process by WRF could lead to plant biomass utilization in ways that improve the overall economy of canola production, as well as contributing to the reduction of wastes and pollution from canola production and applications.

\section{Acknowledgements}

The work was supported by USDA-ARS-Evans-Allen funds provided to North Carolina A\&T State University. Trade or manufacturers' names mentioned are for information only and do not constitute endorsement, recommendation, or exclusion by North Carolina A\&T State University, Alabama A \& M University and collaborating Universities.

\section{References}

[1] El Bassam, N. (2010) Handbook of Bioenergy Crops. Earthscan, Oxford, UK.

[2] Blenis, P.V., Chow, P.S. and Stringam, G.R. (1999) Effects of Burial, Stem Portion and Cultivar on the Decomposition of Canola Straw. Canadian Journal of Plant Science, 79, 97-100. http://dx.doi.org/10.4141/P98-022

[3] Adapa, P.K., Schoenau, G.J. Tabil, L.G., Sokhansanj, S. and Crerar, B.J. (2003) Pelleting of Fractionated Alfalfa Products. ASABE Paper No.036069, ASABE, St. Joseph.

[4] Szczodrak, J. and Fiedukek, J. (1996) Technology for Conversion of Lignocellulosic Biomass to Ethanol. Biomass and Bioenergy, 10, 367-375. http://dx.doi.org/10.1016/0961-9534(95)00114-X

[5] Wyman, C.E., Dale, B.E., Elander, R.T., Holtzapple, M., Ladisch, M.R. and Lee, Y.Y. (2005) Comparative Sugar Recovery Data from Laboratory Scale Application of Leading Pretreatment Technologies to Corn Stover. Bioresource Technology, 96, 2026-2032. http://dx.doi.org/10.1016/j.biortech.2005.01.018

[6] Van Holme, R., Morreel, K., Ralph, J. and Boerjan, W. (2008) Lignin Engineering. Plant Biology, 11, $278-285$.

[7] Quiroz-Castañeda, R.E., Balcázar-López, E., Dantán-González, E., Martinez, A., Folch-Mallol, J. and Anaya, C.M. (2009) Characterization of Cellulolytic Activities of Bjerkandera adusta and Pycnoporus sanguineus on Solid Wheat Straw Medium. Microbial Biotechnology, 12. http://dx.doi.org/10.2225/vol12-issue4-fulltext-3

[8] Zabel, R.A. and Morrell, J.J. (1992) Wood Microbiology: Decay and Its Prevention. Academic Press, London.

[9] Kurt, S. and Buyukalaca, S. (2010) Yield Performances and Changes in Enzyme Activities of Pleurotus spp. (P. ostreatus and P. sajor-caju) Cultivated on Different Agricultural Wastes. Bioresource Technology, 101, 3164-3169. http://dx.doi.org/10.1016/j.biortech.2009.12.011

[10] Isikhuemhen, O.S., Nerud, F. and Vilgalys, R. (2000) Cultivation Studies on Wild and Selected Hybrid Strains of Pleurotus tuberregium. World Journal of Microbiology and Biotechnology, 16, 431-435. http://dx.doi.org/10.1023/A:1008958319418

[11] Salmones, D., Mata, G. and Waliszewski, K.N. (2005) Comparative Culturing of Pleurotus spp. on Coffee Pulp and Wheat Straw: Biomass Production and Substrate Biodegradation. Bioresource Technology, 96, 537-544. http://dx.doi.org/10.1016/j.biortech.2004.06.019

[12] Akin, D.E., Rigsby, L.L., Sethuraman, A., Morrison, W.H., Gamble, G.R. and Eriksson, K.E.L. (1995) Alterations in Structure, Chemistry, and Biodegradability of Grass Lignocellulose Treated with the White Rot Fungi Ceriporiopsis subvermispora and Cyathus stercoreus. Applied and Environmental Microbiology, 61, 1591-1598.

[13] Chen, J., Fales, S.L., Varga, G.A. and Royse, D.J. (1995) Biodegradation of Cell Wall Components of Maize Stover Colonized by White-Rot Fungi and Resulting Impact on in Vitro Digestibility. Journal of the Science of Food and Agriculture, 68, 91-98. http://dx.doi.org/10.1002/jsfa.2740680115

[14] Karunanandaa, K., Varga, G.A., Akin, D.E., Rigsby, L.L. and Royse, D.J. (1995) Botanical Fractions of Rice Straw Colonized by White-Rot Fungi: Changes in Chemical Composition and Structure. Animal Feed Science and Technolo- 
gy, 55, 179-199. http://dx.doi.org/10.1016/0377-8401(95)00805-W

[15] Koutrotsios, G., Mountzouris, K.C., Chatzipavlidis, I. and Zervakis, G.I. (2014) Bioconversion of Lignocellulosic Residues by Agrocybe cylindracea and Pleurotus ostreatus Mushroom Fungi-Assessment of Their Effect on the Final Product and Spent Substrate Properties. Food Chemistry, 161, 127-135.

http://dx.doi.org/10.1016/j.foodchem.2014.03.121

[16] Isikhuemhen, O.S., Mikiashvili, N.A., Adenipekun, C.O., Ohimain, E.I. and Shahbazi, G. (2012) The Tropical White Rot Fungus, Lentinus squarrosulus Mont: Lignocelluloytic Enzymes Activities and Sugar Release from Cornstalks under Solid State Fermentation. World Journal of Microbiology and Biotechnology, 28, 1961-1966. http://dx.doi.org/10.1007/s11274-011-0998-6

[17] Sun, Y. and Cheng, J. (2002) Hydrolysis of Lignocellulosic Materials for Ethanol Production: A Review. Bioresource Technology, 83, 1-11. http://dx.doi.org/10.1016/S0960-8524(01)00212-7

[18] Ohgren, K., Bura, R., Saddler, J. and Zacchi, G. (2007) Effect of Hemicelluloses and Lignin Removal on Enzymatic Hydrolysis of Steam Pretreated Corn Stover. Bioresource Technology, 98, 2503-2510. http://dx.doi.org/10.1016/j.biortech.2006.09.003

[19] Ntougias, S., Baldrian, P., Ehaliotis, C., Nerud, F., Antoniou, T., Merhautová, V. and Zervakis, G.I. (2012) Biodegradation and Detoxification of Olive Mill Wastewater by Selected Strains of the Mushroom Genera Ganoderma and Pleurotus. Chemosphere, 88, 620-626. http://dx.doi.org/10.1016/j.chemosphere.2012.03.042

[20] Wariishi, H., Valli, K. and Gold, M.H. (1991) In Vitro Depolymerization of Lignin by Manganese Peroxidase of Phanerochaete chrysosporium. Biochemical and Biophysical Research Communications, 176, 269-275. http://dx.doi.org/10.1016/0006-291X(91)90919-X

[21] Gutiérrez, A., Martinez, M.J., Almendros, G., González-Vila, F.J. and Martinez, A.T. (1995) Hyphal-Sheath Polysaccharides in Fungal Deterioration. Science of the Total Environment, 167, 315-328. http://dx.doi.org/10.1016/0048-9697(95)04592-O

[22] Catley, B.J. (1992) The Biochemistry of Some Fungal Polysaccharides with Industrial Potencial. In: Arora, D., Elander, R.P. and Mukerji, K.G., Eds., Handbook of Applied Mycology: Fungal Biotechnology, Marcel Dekker, New York, 259279.

[23] Sharma, R.K. and Arora, D.S. (2011) Biodegradation of Paddy Straw Obtained from Different Geographic Locations by Means of Phlebia spp. for Animal Feed. Biodegradation, 22, 143-152. http://dx.doi.org/10.1007/s10532-010-9383-7

[24] Van Soest, P.J., Robertson, J.B. and Lewis, B.A. (1991) Methods for Dietary Fiber, Neutral Detergent Fiber, and Nonstarch Polysaccharides in Relation to Animal Nutrition. Journal of Dairy Science, 74, 3583-3597. http://dx.doi.org/10.3168/jds.S0022-0302(91)78551-2

[25] Isikhuemhen, O.S. and Nerud, F. (1999) Preliminary Studies on the Ligninolytic Enzymes Produced by the Tropical Fungus Pleurotus tuber-regium (Fr.) Sing. Antonie van Leeuwenhoek, 75, 257-260. http://dx.doi.org/10.1023/A:1001871101604

[26] Glenn, J.K. and Gold, M. (1983) Decolorization of Several Polymeric Dyes by the Lignin Degrading Basidiomycete, Phanerochaete chrysosporium. Applied and Environmental Microbiology, 45, 1741-1747.

[27] Ghose, T.K. (1987) Measurement of Cellulase Activities. Pure and Applied Chemistry, 59, 257-268. http://dx.doi.org/10.1351/pac198759020257

[28] Bailey, M.J., Biely, P. and Poutanen, K. (1992) Interlaboratory Testing of Methods for Assay of Xylanase Activity. Journal of Biotechnology, 23, 257-270. http://dx.doi.org/10.1016/0168-1656(92)90074-J

[29] Poutanen, K. and Puls, J. (1988) Characteristics of Trichoderma reesei Beta-Xylosidase and Its Use in the Hydrolysis of Solubilized Xylans. Applied Microbiology and Biotechnology, 28, 425-432. http://dx.doi.org/10.1007/BF00268208

[30] Quesada, A., Galvan, A. and Fernandez, E. (1994) Identification of Nitrate Transporters in Chlamydomonas reinhardtii. Plant Journal, 5, 407-419. http://dx.doi.org/10.1111/j.1365-313X.1994.00407.x

[31] Hammel, K.E. (1997) Fungal Degradation of Lignin. In: Cadisch, G. and Giller, K.E., Eds., Driven by Nature: Plant Litter Quality and Decomposition, CAB International, Wallingford, 33-45.

[32] Rois, S. and Eyzaguirre, J. (1992) Conditions of Selective Degradation of Lignin by the Fungus Ganoderma australis. Applied Microbiology and Biotechnology, 37, 667-669.

[33] Rolz, C., De Leon, R., De Arriola, M.C. and De Cabrera, S. (1986) Biodelignification of Lemon Grass and Citronella Bagasse by White-Rot Fungi. Applied and Environmental Microbiology, 52, 607-611.

[34] Mes-Hartree, M., Yu, E.K.C., Reid, I.D. and Saddler, J.N. (1987) Suitability of Aspenwood Biologically Delignified with Phlebia tremellosus for Fermentation to Ethanol or Butanediol. Applied Microbiology and Biotechnology, 26, 120-125. http://dx.doi.org/10.1007/BF00253894 
[35] Hatakka, A.I. (1983) Pretreatment of Wheat Straw by White-Rot Fungi for Enzymatic Saccharification of Cellulose. European Journal of Applied Microbiology and Biotechnology, 18, 350-357. http://dx.doi.org/10.1007/BF00504744

[36] Mikiashvili, N.A., Isikhuemhen, O.S. and Ohimain, E.I. (2011) Lignin Degradation, Ligninolytic Enzymes Activities and Expolysaccharide Production by Grifola frondosa Strains Cultivated on Oak Sawdust. Brazilian Journal of Microbiology, 42, 1101-1108. http://dx.doi.org/10.1590/S1517-83822011000300031

[37] Barrasa, J.M., Gutiérrez, A., Escaso, V., Guillén, F., Martínez, M.J. and Martínez, A.T. (1998) Electron and Fluorescence Microscopy of Extracellular Glucan and Aryl-Alcohol Oxidase during Wheat-Straw Degradation by Pleurotus eryngii. Applied and Environmental Microbiology, 64, 325-332.

[38] Krcmar, P., Novotny, C., Marais, M.F. and Joseleau, J.P. (1999) Structure of Extracellular Polysaccharide Produced by Lignin-Degrading Fungus Phlebia radiata in Liquid Culture. International Journal of Biological Macromolecules, 24, 61-64. http://dx.doi.org/10.1016/S0141-8130(98)00072-5

[39] McCue, P.P. and Shetty, K. (2005) A Model for the Involvement of Lignin Degradation Enzymes in Phenolic Antioxidant Mobilization from Whole Soybean during Solid-State Bioprocessing by Lentinus edodes. Process Biochemistry, 40, 1143-1150.

[40] Burns, P.J., Yeo, P., Keshavarz, T., Roller, S. and Evans, C.S. (1994) Physiological Studies of Exopolysaccharide Production from the Basidiomycete Pleurotus sp. florida. Enzyme and Microbial Technology, 16, 566-572. http://dx.doi.org/10.1016/0141-0229(94)90120-1

[41] Maziero, R., Cavazzoni, V. and Bononi, V.L.R. (1999) Screening of Basidiomycetes for the Production of Exopolysaccharide and Biomass in Submerged Culture. Revista de Microbiologia, 30, 77-84. http://dx.doi.org/10.1590/S0001-37141999000100015

[42] Elisashvili, V.I., Kachlishvili, E.T. and Wasser, S.P. (2009) Carbon and Nitrogen Source Effects on Basidiomycetes Exopolysaccharide Production. Applied Biochemistry and Microbiology, 45, 531-535. http://dx.doi.org/10.1134/S0003683809050135

[43] Perera, P.K. and Li, Y. (2011) Mushrooms as a Functional Food Mediator in Preventing and Ameliorating Diabetes. Functional Foods in Health and Disease, 4, 161-171.

[44] Lin, T.-C., Chang, J.-S. and Young, C.-C. (2008) Exopolysaccharides Produced by Gordonia alkanivorans Enhances Bacterial Degradation Activity for Diesel. Biotechnology Letters, 30, 1201-1206. http://dx.doi.org/10.1007/s10529-008-9667-8

[45] Tien, M. and Kirk, T.K. (1983) Lignin-Degrading Enzyme from the Hymenomycete Phanerochaete chrysosporium Burds. Science, 221, 661-663. http://dx.doi.org/10.1126/science.221.4611.661

[46] Tien, M. and Kirk, T.K. (1984) Lignin Degrading Enzymes from Phanerocheate chrysosporium: Purification, Characterization, and Catalytic Properties of a Unique $\mathrm{H}_{2} \mathrm{O}_{2}$ Requiring Oxygenase. Proceedings of the National Academy of Sciences of the United States of America, 81, 2280-2284. http://dx.doi.org/10.1073/pnas.81.8.2280

[47] Kovacs, K., Macrelli, S., Szakacs, G. and Zacchi, G. (2009) Enzymatic Hydrolysis of Steam Pretreated Lignocellulisic Materials with Trichoderma atroviride Enzymes Produced In-House. Biotechnology for Biofuels, 2, 14-25. http://dx.doi.org/10.1186/1754-6834-2-14

[48] Boominathan, K. and Reddy, C.A. (1992) cAMP-Mediated Differential Regulation of Lignin Peroxidase and Manganese-Dependant Peroxidase Production in the White Rot Basidiomycete Phanerochaete chrysosporium. Proceedings of the National Academy of Sciences of the United States of America, 89, 5586-5590. http://dx.doi.org/10.1073/pnas.89.12.5586

[49] Duff, S.J.B. and Murray, W.D. (1996) Bioconversion of Forest Products Industry Waste Cellulosics to Fuel Ethanol: A Review. Bioresource Technology, 55, 1-33. http://dx.doi.org/10.1016/0960-8524(95)00122-0 
Scientific Research Publishing (SCIRP) is one of the largest Open Access journal publishers. It is currently publishing more than 200 open access, online, peer-reviewed journals covering a wide range of academic disciplines. SCIRP serves the worldwide academic communities and contributes to the progress and application of science with its publication.

Other selected journals from SCIRP are listed as below. Submit your manuscript to us via either submit@scirp.org or Online Submission Portal.
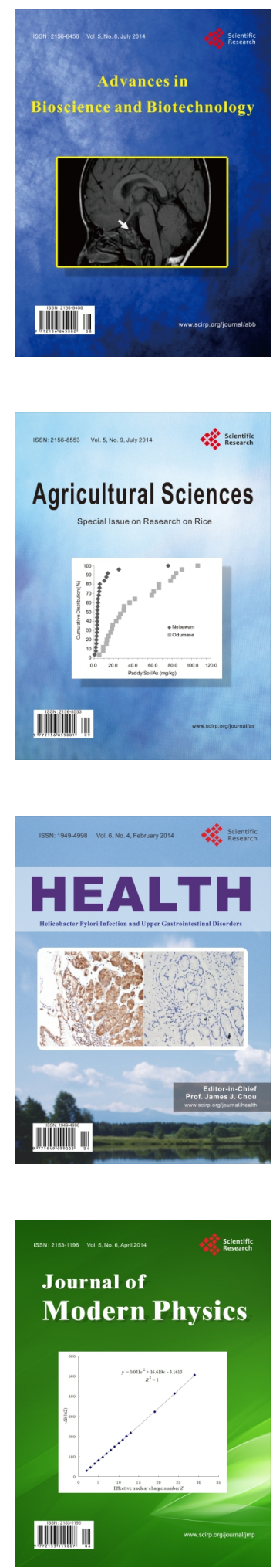
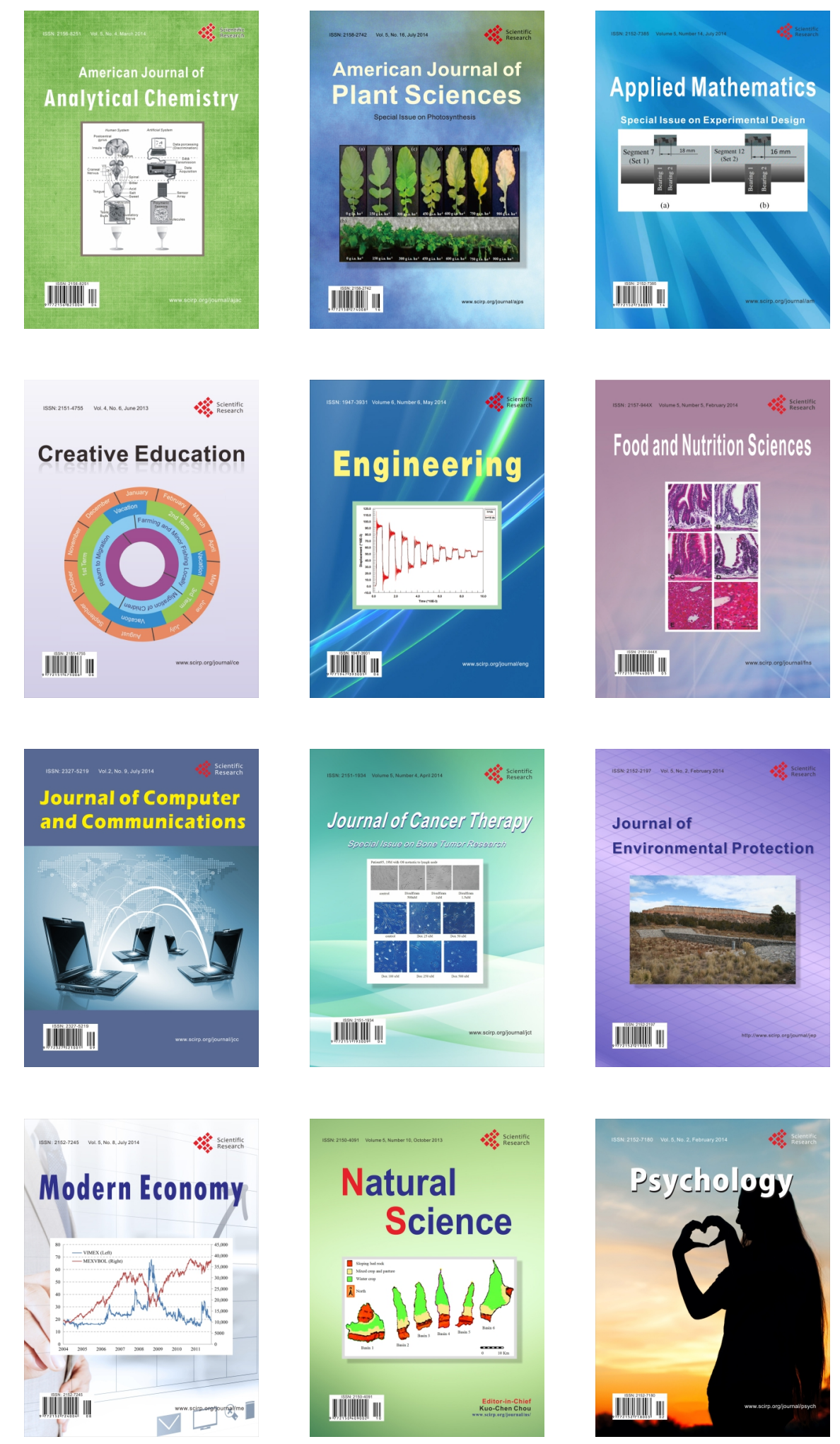